\title{
УДК 82 \\ МАГИЧЕСКИЙ РЕАЛИЗМ В СБОРНИКЕ ЕВГЕНИИ НЕКРАСОВОЙ «СЕСТРОМАМ» КАК СПОСОБ ОСМЫСЛЕНИЯ БЫТОВОЙ ДЕЙСТВИТЕЛЬНОСТИ
}

\author{
Пучкова Анна Викторовна \\ Калужский государственный университет им. К.Э. Циолковского \\ Студентка 4 курса
}

Аннотация. В статье рассматривается тексты сборника Евгении Некрасовой «Сестромам. О тех, кто будет маяться», анализируются рассказы «Павлов», «Сестромам», «Лакшми», «Присуха» с точки зрения магического реализма, предлагается возможный вариант интерпретации, исходя из данной жанровой специфики, раскрывается роль магического реализма для создания символической образности характеров героев.

Annotation. The article examines the texts of the collection of Evgenia Nekrasova "Sestromam. About those who will toil", the stories of "Pavlov", "Sestromam", "Lakshmi", "Drying" are analyzed from the point of view of magical realism, a possible interpretation is offered based on this genre specificity, the role of magical realism for creating symbolic imagery of characters' characters is revealed.

Ключевые слова: магический реализм, Евгения Некрасова, «Сестромам», символы, характеры.

Keywords: magic realism, Evgeniya Nekrasova, "Sestromam", symbols, characters.

Зачастую поведение людей настолько необъяснимо и не поддается рациональному осмыслению, что его можно расценивать только как воздействие внешних, магических или мифологических сил. Что заставляет бросать супругов и уходить к едва знакомым возлюбленным, совершать поступки, на которые другие просто не способны? Что это: оправдание собственной несдержанности или реальное воздействие внешних, непреодолимых сил, которым человек не властен противиться?

Рассказы Евгении Некрасовой в сборнике «Сестромам» поднимают сугубо личные, житейские вопросы. Внешне сюжет далек от осмысления экзистенциальных проблем: герои - «каждый несчастлив по-своему» - не рефлексируют о причинах, ищут лишь пути выхода. Но на простые вопросы не всегда находятся столь же простые ответы, и Евгения Некрасова, используя жанр магического реализма, пытается осмыслить типично реалистические коллизии: властен ли человек на самим собой и своей жизнью; может ли он укротить, «очеловечить» низменные, биологические и темные порывы.

Герой рассказа «Павлов» - немолодой мужчина, жизнь которого - рефлекс, желания - инстинкты, цель удовлетворение физиологических потребностей. Жизнь для Павлова проста: он - самец, а значит, самый сильный: «все должно происходить по правилам. Согласно им, он, Павлов, главный - и его команды должны исполняться» [1, c. 10].

Павлов напоминает сторожевого пса: работает охранником «в маленькой фанерной будке», наблюдает за «агрессивным, воюще-рычащим стадом» машин, покорно стоящих на автостоянке. И интересует его только то, что доставляет удовольствие или приносит прибыль: «пошевелив носом и почуяв... что-то от человека - срамное, физиологическое» $[1$, с. 12], он однажды обнаруживает на своей стоянке «бордель», устроенный на заднем сидении «Волги» и тут же «договаривается-снюхивается» с «тихим техником»-хозяином о доле в столь прибыльном предприятии и возможности наблюдать за процессом.

«На службе - на страже и дома - на страже» [1, с. 10], Павлов сторожит не только покой, здоровье и имущество семьи, но и порядок в ней. Особо нужно держать в ежовых рукавицах сына: «плохо учится; постоянно, щенок, перечит» $[1$, с. 10$]$, следовательно, и воспитывать как положено: «пнул пару раз, зачем - всем понятно» $[1$, с. 10]; «сказал - спортом заниматься, значит, идет сучонок в секцию» [1, с. 10].

Фамилия героя раскрывает его сущность: как и ученый, впервые описавший феномен воздействия на организм внешних раздражителей, Павлов получает ответную реакцию на свой воспитательный метод: сын совершает попытку самоубийства. «И откуда только он, щенок одиннадцатилетний, так подробно узнал, как себя на тот свет отправить? Хорошо, не успел далеко забраться» [1, с. 14]. И после этого у Павлова впервые возникают человеческие, живые мысли: ощущение «укуса вины», который «давит плечи, грудь и брюхо» [1, с. 13].

Животные вины не чувствуют, поскольку руководствуются инстинктами, но сейчас Павлов впервые не только задумывается о своем существовании, но и пытается соизмерить свою жизнь с другими: «а было ли когданибудь у кроткой милиционерши, у позолоченного хирурга, у сообразительного тихого техника или у маринующих друг друга в ругани семей - чувство вины? Хоть за что-нибудь?» [1, с. 14]. Был ли этот вопрос зачатком развития самосознания, осознанности, рефлексии? Вероятно, нет, поскольку Павлов не ищет причины в себе, не подвергает сомнению свои действия, лишь хочет понять: выбиваются ли его мысли из потока окружающей жизни? 
Звонок жены, заставивший оскалиться от страха и принесший новость о том, что сын не умер, отчасти вновь возвращает Павлова к биологическим инстинктам: если особь выжила, значит, винить в себя нечем, но вина не уходит полностью: половина - «с хвоста» - уходит, но ее головная-главная часть остается.

Как можно понять существование Павлова - без рефлексии и эмпатии, человеческих чувств и устремлений? В рассказе отождествление героя с псом позволяет усилить биологичность поступков и усилить гротескность поведения, прием остранения позволяет воспринять иначе характер героя.

Героиня рассказа «Сестромам» Анечка - молодая девушка, «всюду ладненькая». Все в ней хорошо, кроме обременительного долга «мотания, говорения, выслушивания, делания дела» [1, с. 89] по отношению к своей старшей сестре. Лишившись матери, девочки остались без попечения, и роль мамы взяла на себя старшая, превратившись в «треклятого сестромама»: «Не сестра - мама. Сестромам какой-то» [1, с. 89] и посвятила жизнь заботе за младшей: жАнечка жила, Сестромам боромыслил $[1$, c. 90$]$.

Повзрослев и лишившись угнетающей опеки, младшая ловко поступила в университет, затем устроилась на работу, «растворилась в Москве шипучим порошком». А оставшийся в одиночестве Сестромам «осунулся, постарел, вылез на раннюю пенсию по тоске и инвалидности» [1, с. 91]. Анечка же не могла избавиться от чувства вины за то, что оставила Сестромама: не испытывая любви, тяготилась долгом ответственности, которую не хотела брать: «Анечка старалась сама себе у Сестромама не показываться. Терялась тут же вся ее ладность, вся хорошесть» [1, с. 93]. Ощущение вины заставляло чувствовать себя неполноценной: стремление быть хорошей, такой, как все, не соотносилось с брошенной сестрой, посвятившей ее воспитанию жизнь. Это лишь усиливалось тем, что Сестромам не судил, не упрекал: «вина Анечкина настаивалась на сестромамской жертве» [1, с. 93]. Последние часы жизни Сестромама, Анечка, находящаяся рядом, прячется в интернете, «ставя дрожащие лайки, читая посты, пиша сообщения в личке, что Сестромам, кажется, умирает» [1, с. 94]. Ее смерть пробуждает Анечку от «жизнисна» и позволяет снять с себя маску хорошей и примерной: «стала себе мерило всего, приблизительная безмерность. Без вины, с винегретом из ада и рая. У Сестромама душа шагнула из тела, а Анечка сама шагнула из души. Зачем таким мера, из души шагнувшим?» [1, с. 97]. Теперь больше не делая вид, Анечка обретает полную свободу от оков морали: уводит из семьи мужа лучшей подруги, выбрасывает кошку Сестромама и переселяется в Подмосковье, в «квартирай»: «так удобней безмерно жить (в Москве - во всем мера нужна)» [1, с. 97].

Люди, узнав, что Анечка живет без вины, стали приходить с просьбами выполнить то, на что сами не были способны: отравить мужа-пьяницу, который «после развода не уходит, денег не дает, пьет, ребенка бьет» [1, с. 97]. И Анечка, как темный ангел, «сверху прилетела, крылышком махнула, водку подменила. Соседа через два дня в коробку сложили и вынесли, как пса отлаявшего» [1, с. 100]. После явился Сестромам в обличье птицы Гамаюн и сообщил итог Анечкиного деяния: «грех на душу - попусту»: дочь выберет такого же мужа, который будет избивать и ее, и мать. Но «шагнувших не волнует. Они вины, боли, страха, радости не чуют» [1, с. 103].

И после жестокого издевательства над парнем, обижающим мальчика-соседа, и поцарапанной машины мужа подруги - каждый раз является гамаюн-Сестромам и сообщает страшный результат «помощи». Но после просьбы «дачницы-помидорницы» сбросить «конкурентку-перепродажницу по ходу поезда» [1, с. 104], во время выполнения которой Анечку выкинули из вагона саму, гамаюн-Сестромам поведал, что уехавшая из-за сорванной вахты домой продавщица «вовремя к матери успеет, которую вот-вот хватит удар...» [1, с. 105]. После искупления чувства вины, испытываемого из-за смерти сестры, спасением жизни другому человеку, «шагнувшая из тела» душа вновь возвращается, Анечка обретает себя, а Сестромам отправляется в рай, где встречается с мамой.

Анечка после смерти сестры, для того чтобы заглушить сильнейшее чувство вины, решает абстрагироваться от эмоций вообще - надеть маску «бесчувственной». Но поступок, спасший другого человека и искупивший тем самым грех за смерть сестры, вновь возвращает душу в тело.

Саша, героиня рассказа «Присуха», была счастлива с мужем Сашей, даже имена которых, как казалось, «судьба зарифмовала», до того самого момента, как полюбила другого. Безответное чувство, отягощенное виной перед мужем, лишает ее покоя. Все сошлось к одному: «равнодушие нянчит ненависть к любящему» [1, с. 206], да и сам Саша «будто специально влез в свою важную серьезную работу по уши» [1, с. 205], не замечает изменений в жене, чем лишь усугубляет ситуацию.

Что заставляет человека поменять тихое, спокойное, безмятежное счастье на искания, борения, боль и тоску по другому? Почему столько людей уходит из кажущихся благополучными семей и выбирают неизвестность? В рассказе Евгении Некрасовой объяснение магическое: присуха - обряд приворота, который вызывает непреодолимую тоску:

Сушись, красна девица,

Суиись от пяток до макуики,

Суиись-засуиивайся,

Сохни по рабу Божьему Евгеньеву. [1, с. 203]

Домовой в рассказе становится «голосом разума», оберегающим семейный очаг, благополучие в доме: «мохнатый чуял, что творится с хозяйкой» [1, с. 202], «застыдился, проохал неслышное людям: «"Грех-грех! "» [1, с. 200], а птица-Гамаюн - олицетворением чувственности: «закон любви не писан» [1, с. 239]. 
Любовь к другому изменила Сашу до неузнаваемости: «раньше молилась, чтобы Саша длился вечно. Теперь страшно, что он - навсегда» [1, с. 207]. Подруги советовали разное: одна - уйти к «своему человеку», вторая родить от мужа, забыться в быте. А третья, ведающая в колдовстве, раскрыла «истинную» причину чувства присуха. «Присушили. Любовным заговором. И не от любви, а от сильной злобы. Человек Сашин сам писалстарался» [1, с. 212].

Кто же «присушил»? Пряжин, работник музея, которому Саша отказалась помогать реализовывать творческий проект, нисколько ее не заинтересовавший: «музей хлама, музей фигни, музей в яме, музей-овраг» $[1$, c. 217].

Решив открыть мужу истинные чувства, она встречает непонимание: «Саша понял только, что Саша его не любит больше, полюбила другого и врет ересью про заговоры и прочую ерунду. Унижает его таким враньем» [1, c. 223].

Евгеньев (потому что жена Пряжина - Евгения - «словозащита») принял ее равнодушно, и тогда Саша решает действовать: сама начинает создавать присухи и активно «кликать» в социальных сетях. И это работает: Пряжин собирается уходить от жены и ехать к Саше, а Саша готовится встречать «своего человека». Но чары вдруг утрачивают катастрофическую и непреодолимую силу: Евгеньев в последний момент поддается просьбе жены купить масла и, вернувшись домой, уже никуда не едет; после времени отхода поезда даже чувствует облегчение. Саша же просто отключает будильник, «обнимает Сашу и падает в сон» [1, с. 242].

Что же становится причиной того, что идиллия не состоялась? Слабость присухи, снятие порчи или все же разум, возобладавший над импульсом чувств? В рассказе ответ неочевиден и очевиден одновременно. Природу чувств понять невозможно, но в бытовой, а не магической реальности необходимо контролировать действия, вне зависимости от того, какова их причина.

Героиня рассказа «Лакшми» Лера, вышедшая замуж за Овражина от безысходности: дома пьет отчим, страдает мать - «сама еще не выросла. Она не понимала и не знала, чего хочет. Ее не спрашивали. Пять лет назад она перестала играть в куклы» [1, с. 245], а сейчас уже воспитывает двоих детей. Но настоящая жизнь - не сказка: в Пункте, где работа передается по наследству, а увольнение равносильно самоубийству, мужа смещают с должности шофера: «Лера знала, что он никогда не найдет себе места. Он и не искал себе места» [1, с. 248].

Овражин, находясь в подавленном состоянии, вдруг впервые по-настоящему осознанно видит свой обреченный, грустный город и «застрадав», начинает пить. Лера, терпевшая запой мужа пять дней, решается заговорить о поиске новой работы, и тогда Овражин впервые поднимает на нее руку. Такое положение в семье для нее не было новым: отчим постоянно бил мать, а потому она удивляется скорее от неожиданности, чем от самого факта побоев: «легла спать с мужем. Больше некуда, Овражины жили в однушке» [1, с. 250].

На следующий же день Овражин видит «чудо»: встречает двух смеющихся старух, да и в целом кажется, что «Пункт вроде как подтянулся» [1, с. 250]. Воодушевленный Овражин, придя домой, не видит восторга жены, и, разозлившись, избивает ее во второй раз. И на следующий день происходит второе чудо: «мебельную фабрику купил некрупный феодал из Гулливерии. Город зашатался, задышал часто в предвкушении новых рабочих мест» [1, с. 254], а на улице вдруг появляется много радостных лиц и симпатичных людей.

Выявив причинно-следственную связь между побоями жены и развитием Пункта, Овражин вдруг «прозревает»: «счастье находится в его собственных руках. Все указывало на это...Пункт - город-счастья, Овражин - человек-герой!» [1, с. 254]. Теперь он бьет жену каждый вечер, а утром выходит на улицу «собирать плоды». Все это Овражин считает своей заслугой. Бить любимую жену сложно. «Приходилось по-настоящему, он проверял: толчки и постукивания не засчитывались» $[1$, с. 255]. Он даже полюбил жену сильнее, ведь она одна страдает за целый пункт. Овражин не искал работу, он сейчас делал то дело, для которого родился, осчастливливал.

Сперва Лера пытается искать причину в себе, но вскоре просто отчаивается. Овражин же «ходит героем и светит счастьем» $[1$, с. 258$]$, за что его и берут работать шофером на новую фабрику. А когда почувствовал, что жена «смирилась» и настало время «осчастливить, открыться ей»- он растолковывает свою миссию: «говорит, что она - праведная, юродивая, единственная, важнейшая; он - всего лишь герой, а она - святая, спасительница пункта» [1, с. 259]. И Лера наконец понимает причину поведения мужа: «просто сошел с ума» [1, с. 259].

Но как же прекратить эти мучения? Уйти от сумасшедшего, забрав детей? Нет, женщина надеется лишь на чудо. И чудо происходит: у Леры во время очередного избиения вдруг вырастают дополнительные руки: «Внезапно она схватила его за горло.... Застыла и только сейчас рассмотрела, что одной парой держит Овражина за горло, а другой - сковывает его руки» [1, с. 262]; и впервые возникает «новое, незнакомое ей ощущение...страсть, пульсирующее желание счастья. Счастливого переворота» [1, с. 268]. После неожиданного отпора жены Овражин, совсем не способный терпеть боль, сам вызывает «скорую» и пролежав в больнице три недели, навсегда убегает из Пункта.

Отчего же у Леры возникают четыре пары рук, как у Лакшми - богини благополучия, изобилия, процветания, богатства, удачи и счастья? Для того, чтобы сделать пункт лучше? А может - для того, чтобы дать отпор мужу? В финале рассказа история превращается в городской фольклор: «с тех пор говорили, то во многих пунктах у женщин стали вырастать дополнительные руки, чтобы отбиваться от мужей и сожителей» [1, с. 273]. Лишние 
руки, за ненадобностью, после побега Овражина, исчезают, и Лера наконец «вырастает» и становится настоящей, зрелой женщиной: «повзрослела и помолодела одновременно... сама она забыла страх, гнев, равнодушие, нашла работу-чудо и стала ощущать не счастье, а частую, объемную радость» [1, с. 274].

Почему вместо решительных действий жертвы насилий выбирают смирение, надежду на чудо, неожиданное спасение? Для насильника окружающий мир и правда преображается: удовлетворение животной потребности выместить свою злобу и ярость на безответном, слабом существе всегда доставляет удовольствие и повышает настроение. В рассказе Леру спасает лишь чудо - на деле, ей и правда необходимы дополнительные руки - руки помощи других, способные защитить ее, вытащить из безысходности, спасти от мучений.

В сборнике рассказов Евгении Некрасовой «Сестромам» действуют различные силы: магические, фольклорные, мифологические. Но все рассказы объединены общим мотивом: призывом к человечности к обретению целостного «Я»- социального и личностного. Прием остранения, выраженный во введении элементов магического осмысления мира, для которого характерно принятие того факта, что человек не властен над собой и реальностью, в реалистическом произведении лишь усиливает бытовой характер коллизии, выводит на первый план то, что поведение героев - это исключительно их воля, их желание. Не важна причина возникновения ситуации - важно всегда оставаться человеком.

\section{ЛИТЕРАТУРА:}

1. Некрасова, Евгения Игоревна. Сестромам. О тех, кто будет маяться : [рассказы, повести] / Евгения Некрасова. - Москва : Издательство АСТ : Редакция Елены Шубиной, 2019. - 379, [5] с. 